\title{
Targeting the NMDA receptor-nitric oxide-cyclic GMP pathway to develop non-dopaminergic antipsychotic medications for schizophrenia
}

\section{A via receptor NMDA-óxido nítrico-GMP cíclico como alvo para o desenvolvimento de medicações antipsicóticas não- dopaminérgicas para a esquizofrenia}

Schizophrenia is a devastating disorder that occurs in about $1 \%$ of the population worldwide. For over 30 years, it has been considered to be the result of dysfunctional brain dopaminergic pathways. However, dopaminergic antipsychotic drugs have proven effective for only some of the symptoms found in schizophrenia patients. Recent evidence suggests that dopaminergic abnormalities may be secondary to dysfunctions in multi-neurotransmitter systems modulating dopamine. One of the key neurotransmitters thought to be involved in schizophrenia is glutamate, and there is strong support for the involvement of a hypoactivity of N-methyl-D-aspartate (NMDA) glutamate receptors in the pathogenesis of schizophrenia. However, research with NMDA receptor agonists for the treatment of schizophrenia has produced inconsistent results, which may be due to the development of rapid tolerance to these compounds secondary to down-regulation of NMDA receptors. Perhaps the development of drugs that act on targets downstream NMDA receptors, such as nitric oxide (NO), could avoid the problem of the down-regulation of these receptors.

\section{The NMDA-NO-cyclicGMP pathway}

The activation of NMDA receptors by glutamate results in calcium influx into the cell; where calcium binds to calmodulin and stimulates the nNOS (neuronal nitric oxide synthase) enzyme to produce $\mathrm{NO}$ in the nervous system. Nitric oxide activates guanylate cyclase, which increases the production of cyclic GMP. This NMDA-NOcyclicGMP pathway has been shown to modulate the release of neurotransmitters such as glutamate and dopamine. Although the direction of these abnormalities is still under debate, this pathway has been consistently implicated in schizophrenia ${ }^{1}$.

\section{Nitric Oxide}

$\mathrm{NO}$ is a gas that acts by mediating cellular communication in many ways in the nervous system. Its mechanism of action involves an increase in the concentrations of the second messenger cyclic GMP through activation of the soluble guanylate cyclase enzyme. $\mathrm{NO}$ is endogenously produced by the conversion of L-arginine into L-citrulline by $\mathrm{NO}$ synthase (NOS) ${ }^{2}$.
There are three known isoforms of NOS, namely the inducible form iNOS (expressed in macrophages, neutrophils, fibroblasts, vascular smooth muscles, and endothelial cells in response to pathological stimuli) and two forms called constitutive, which are present in the endothelium (eNOS) and neurons (nNOS) under normal physiologic conditions.

In the CNS, NO has been shown to influence the release of neurotransmitters, learning and memory, and neurodevelopment.

Therefore, growing evidence indicates that $\mathrm{NO}$ plays a predominant role in neuronal maturation and synaptogenesis during neuronal development. Thus, disturbances in NO release could interfere with both the maturation of cortical neurons and the formation of viable synaptic connections, in accordance with the neurodevelopmental hypothesis of schizophrenia.

\section{Cyclic GMP}

The stimulation of soluble guanylate cyclase by NO leads to increased synthesis of cGMP, a second messenger, which in turn influences the activity of kinase cascades, mRNA stability and translation, transcription factors and primary gene products in target cells. Some studies have reported an increase in cerebrospinal fluid levels of cyclic GMP in patients with schizophrenia after treatment with antipsychotic drugs ${ }^{3-5}$. As mentioned above, $\mathrm{NO}$ increases the concentration of cyclic GMP through the activation of soluble guanylate cyclase. It is possible that this increase in cyclic GMP found in these three studies might be related to the stimulation by antipsychotic drugs of the NMDA-NO-cGMP pathway. We predict that the modulation of this pathway and increasing levels of $\mathrm{NO}$ in the CNS will be a productive target to pursue in the future development of antipsychotic drugs.

João Paulo Maia de Oliveira

Department of Neuroscience and Behavior, Faculdade de Medicina de Ribeirão Preto (FMRP), Universidade de São Paulo (USP), Ribeirão Preto, SP, Brazil

Department of Clinical Medicine, Universidade Federal do Rio Grande do Norte, Natal, RN, Brazil 
Bruno Lobão

Department of Biophysics and Pharmacology, Universidade

Federal do Rio Grande do Norte, Instituto Internacional de Neurociências de Natal Edmond \& Lily Safra, Natal, RN, Brazil

João Paulo Machado-de-Sousa

Department of Neuroscience and Behavior, Faculdade de Medicina de RibeirãoPreto (FMRP), Universidade de São Paulo

(USP), Ribeirão Preto, SP, Brazil

Glen B. Baker

Neurochemical Research Unit and Bebensee Schizophrenia Research Unit, Department of Psychiatry, University of Alberta, Edmonton, Alberta, Canada

Instituto Nacional de Ciência e Tecnologia - Translacional em Medicina, Conselho Nacional de Desenvolvimento Científico e Tecnológico (CNPq), Brazil
Serdar Dursun

Neurochemical Research Unit and Bebensee Schizophrenia Research Unit, Department of Psychiatry, University of Alberta, and Centre for Psychiatric Assessment and Therapeutics, Alberta Hospital Edmonton, Alberta Health Services, Edmonton, Alberta, Canada Instituto Nacional de Ciência e Tecnologia - Translacional em Medicina, Conselho Nacional de Desenvolvimento Científico e Tecnológico (CNPq), Brazil

Jaime E. C. Hallak

Department of Neuroscience and Behavior, Faculdade de Medicina de Ribeirão Preto (FMRP), Universidade de São Paulo (USP), Ribeirão Preto, SP, Brazil Instituto Nacional de Ciência e Tecnologia - Translacional em Medicina, Conselho Nacional de Desenvolvimento Científico e Tecnológico (CNPq), Brazil

Disclosures

\begin{tabular}{|c|c|c|c|c|c|c|c|}
\hline $\begin{array}{l}\text { Writing group } \\
\text { member }\end{array}$ & Employment & $\begin{array}{l}\text { Research } \\
\text { grant }^{1}\end{array}$ & $\begin{array}{c}\text { Other } \\
\text { research } \\
\text { grant or } \\
\text { medical } \\
\text { continuous } \\
\text { education }^{2}\end{array}$ & $\begin{array}{l}\text { Speaker's } \\
\text { honoraria }\end{array}$ & $\begin{array}{l}\text { Ownership } \\
\text { interest }\end{array}$ & $\begin{array}{c}\text { Consultant/ } \\
\text { Advisory } \\
\text { board }\end{array}$ & Other $^{3}$ \\
\hline Oliveira JPM & UFRN & CNPq & - & $\begin{array}{l}\text { AstraZeneca } \\
\text { Jansen-Cilag }\end{array}$ & - & - & - \\
\hline Lobão B & $\begin{array}{c}\text { UFRN } \\
\text { IINN-ELS }\end{array}$ & $\begin{array}{c}\text { CNPq } \\
\text { FAPERN }\end{array}$ & - & - & - & - & - \\
\hline $\begin{array}{c}\text { Machado-de-Sousa } \\
\text { JP }\end{array}$ & $\begin{array}{l}\text { FMRP-USP } \\
\text { INCT-TM }\end{array}$ & FAPESP & - & - & - & - & - \\
\hline Baker GB & $\begin{array}{l}\text { University of Albert } \\
\text { Alberta Hospital } \\
\text { Edmonton } \\
\text { INCT-TM }\end{array}$ & - & - & - & - & - & - \\
\hline Hallak JEC & $\begin{array}{l}\text { FMRP-USP } \\
\text { INCT-TM }\end{array}$ & - & - & - & - & - & - \\
\hline \multicolumn{8}{|c|}{$\begin{array}{l}\text { *Modest } \\
\text { ** Significant } \\
\text { *** Significant: Amounts given to the author's institution or to a colleague for research in which the author has participation, not directly to the } \\
\text { author. } \\
\text { Notes: UFRN = Universidade Federal do Rio Grande do Norte; FAPESP = Fundação de Amparo à Pesquisa do Estado de São Paulo; } \\
\text { FAPERN = Fundação de Amparo à Pesquisa do Estado Rio Grande do Norte; CNPq = Conselho Nacional de Desenvolvimento Científico e } \\
\text { Tecnológico; INCT-TM = Instituto Nacional de Ciência e Tecnologia Translacional em Medicina; FMRP-USP = Faculdade de Medicina de } \\
\text { Ribeirão Preto - Universidade de São Paulo; IINN-ELS = Instituto Internacional de Neurociências de Natal Edmond \& Lily Safra }\end{array}$} \\
\hline
\end{tabular}

References

1. Oliveira JP, Zuardi AW, Hallak JE. Role of nitric oxide in patients with schizophrenia- a systematic review of the literature. Curr Psychiatry Rev. 2008;4:219-27.

2. Bredt DS, Snyder SH. Nitric oxide, a novel neuronal messenger. Neuron. 1992;8(1):3-11.

3. Ebstein RP, Biederman J, Rimon R, Zohar J, Belmaker RJ. Cyclic GMP in the CSF ofpatients with schizophrenia before and after neuroleptic treatment. Psychopharmacology (Berl). 1976;51(1):71-4.
4. Gattaz WF, Carmer H, Beckmann H. Low CSF concentrations of cyclic GMP in schizophrenia. Br J Psychiatry. 1983;142:288-91.

5. Ziimmer R, Teelken AW, Cramer H, Ackenheil M, Zandler KJ, Fischer H. Short- and long-term effects on GABA and dopamine neurons during treatment with sulpiride. Adv Biochem Psychopharmacol. 1980;24:537-9. 